\title{
Water Erosion, its Relationship to Total Suspended Solids and Water Quality in the Lower Basin of the Usumacinta River, Tabasco, Mexico
}

\author{
G. Rodríguez-Martínez*†, I. Galaviz-Villa*, S. Partida-Sedas**, C.A. Sosa-Villalobos*, R. de G. Bernal-Ramírez*, \\ V. Alcántara-Méndez* and A. García-Saldaña** \\ *Tecnológico Nacional de México/Instituto Tecnológico de Boca del Río, carretera Veracruz- Córdoba km 12 C.P. \\ 94290. Boca del Río, Veracruz, México. \\ **Tecnológico Nacional de México/ Instituto Tecnológico Superior de Huatusco, Av. 25 Poniente No.100, col. Reserva \\ Territorial Huatusco, Veracruz, México, C.P. 94100. \\ †Corresponding author: G. Rodríguez-Martínez; guadaluperguezmtz@ gmail.com
}

Nat. Env. \& Poll. Tech.

Website: www.neptjournal.com

Received: 10-09-2020

Revised: 23-11-2020

Accepted: $12-12-2020$

Key Words:

Agricultural waste

Erosion risk

Loss of fertile soil

Water quality

\begin{abstract}
Total suspended solids are an indicator of material constituted by sedimentable solids, suspended solids, and colloidal, whose origin is erosion, wastewater discharges, and agricultural waste. The objective of this research was to determine territorial water erosion, its relation with total suspended solids, and the water quality in the lower basin of the Usumacinta River in Tabasco. Three sampling points were established, located in the municipalities of Tenosique, Emiliano Zapata, and Jonuta, in the state of Tabasco. Water samples were collected during 12 monthly sampling campaigns in an annual cycle, and the total suspended solids were determined according to the provisions of the NMX-AA-034-SCFI-2015 standard. Water erosion was calculated based on the Universal Soil Loss Equation (USLE) and with the use of geographic information systems (GIS). The results obtained were statistically analyzed, finding that the measured maximum TSS concentrations are $130.92 \mathrm{mg} \cdot \mathrm{L}^{-1}$ in Boca del Cerro, $165.28 \mathrm{mg} \cdot \mathrm{L}^{-1}$ in Chablé, and $113.91 \mathrm{mg} \cdot \mathrm{L}^{-1}$ in Jonuta which are within the permissible concentrations for protection of freshwater aquatic life and agricultural irrigation according to ecological criteria of water quality (CECCA-001/89), in Mexico. The lower basin of the Usumacinta River has areas with extreme erosion (990 tons. $\mathrm{ha}^{-1} \mathrm{yr}^{-1}$ ), with conditions that accelerate the erosion process, such as annual rainfall between 1805 $\mathrm{mm}$ and $2250 \mathrm{~mm}$, clay soils located on slopes greater than $16 \%$, and agricultural soils. These events cause loss of the soil fertile layer where agriculture is developed, also giving rise to the accelerated transport of suspended solids; which negatively alter the quality of the water of the Usumacinta River.
\end{abstract}

\section{INTRODUCTION}

Of the total border basins in Mexico, the Usumacinta River is the one with the largest extension and hydrological development. It covers an area of more than seven million hectares distributed in three countries; $58 \%$ correspond to Guatemala, $41.91 \%$ to Mexico, and $0.001 \%$ to Belize (Soares \& García 2017). According to its physical characteristics of relief, hydrology, and altitude, the Usumacinta River basin can be divided into three sectors: low basin $(21.5 \%)$, medium $(48.5 \%)$, and high $(30 \%)$ (March \& Castro 2010). Tabasco's economy is based on the development of agriculture, livestock, forestry, fishing, industry, commerce, and tourism; agriculture and livestock being the main activities in the municipalities of Tenosique, Emiliano Zapata, and Jonuta (INEGI 2016). These activities cause soil degradation from the physical, chemical, and biological point of view, manifesting as erosion (Alvarado-Cardona et al. 2007).
At present, there is a combination of factors that accelerate the erosion phenomenon of the GrijalvaUsumacinta basin, causing $83 \%$ to present a medium to a high level of erosion risk, and only $17 \%$ present a low-risk level (Sánchez-Hernández et al. 2013). Eroded soil is transported by runoff to surface water bodies, turning into sediments. In this regard, Paz González (2004) indicated that when the drag force decreases, the thicker particles begin to settle in areas of less slope, while the finer materials are often held in suspension in the perennial stream.

Total suspended solids in surface water are an indicator of material constituted by sedimentable solids, suspended solids, and colloidal, whose origin is wastewater discharges, soil erosion, and agricultural waste (CONAGUA 2018). Suspended solids modify the penetration of light in water in addition to affecting photosynthesis, temperature, and turbidity processes (Vargas \& Linero 2017). Therefore, the objective of this work was to determine territorial water 
Table 1: Geographical location of sampling sites.

\begin{tabular}{|llll|}
\hline Municipality & Sampling site & \multicolumn{2}{l|}{$\begin{array}{l}\text { UTM Coordinates 15 N } \\
\text { Zone }\end{array}$} \\
\cline { 3 - 4 } & & $(\mathrm{X})$ & $(\mathrm{Y})$ \\
\hline Tenosique & $\begin{array}{l}\text { Puente Boca del } \\
\text { Cerro (R1) }\end{array}$ & 660265.3 & 1927441.6 \\
Emiliano Zapata & Puente Chablé (R2) & 628676.6 & 1974718.7 \\
Jonuta & Puente Jonuta (R3) & 587847.4 & 2001480.2 \\
\hline
\end{tabular}

erosion, its relation with total suspended solids, and the water quality of the lower basin of the Usumacinta River.

\section{MATERIALS AND METHODS}

\section{Study Area}

Sampling sites are located in the municipalities of Tenosique, Emiliano Zapata, and Jonuta in the state of Tabasco (Table 1, Fig. 1).

\section{Sampling}

Ten sampling campaigns were carried out from May to December 2018, and from May to June 2019. Water samples were collected monthly based on the CAQAF4-01 procedure, which establishes methodology and criteria for collecting, handling, packaging, preserving, and transferring samples, during prevailing seasons in Tabasco - rainy (June-November) and dry season (December-May). In addition, 20 composite soil samples were collected (each one made up of 16 subsamples or simple samples), in accordance with the procedure established by NOM-021-RECNAT-2000, which establishes specifications for fertility, salinity and soil classification, study, sampling, and analysis.

\section{Laboratory Analysis}

Total suspended solids (TSS) were characterized in surface waters of the lower basin of the Usumacinta River, Tabasco, according to the method established in the NMX-AA-034SCFI-2015 standard. The granulometric analysis and the determination of soil texture were carried out in accordance with the AS-28 and AS-09 methods established in NOM021-RECNAT-2000.

\section{Statistical Analysis}

Descriptive statistics was used to compare the results of physicochemical analyzes with the Ecological Criteria for Water Quality (CE-CCA-001/89) in Mexico, and interna-

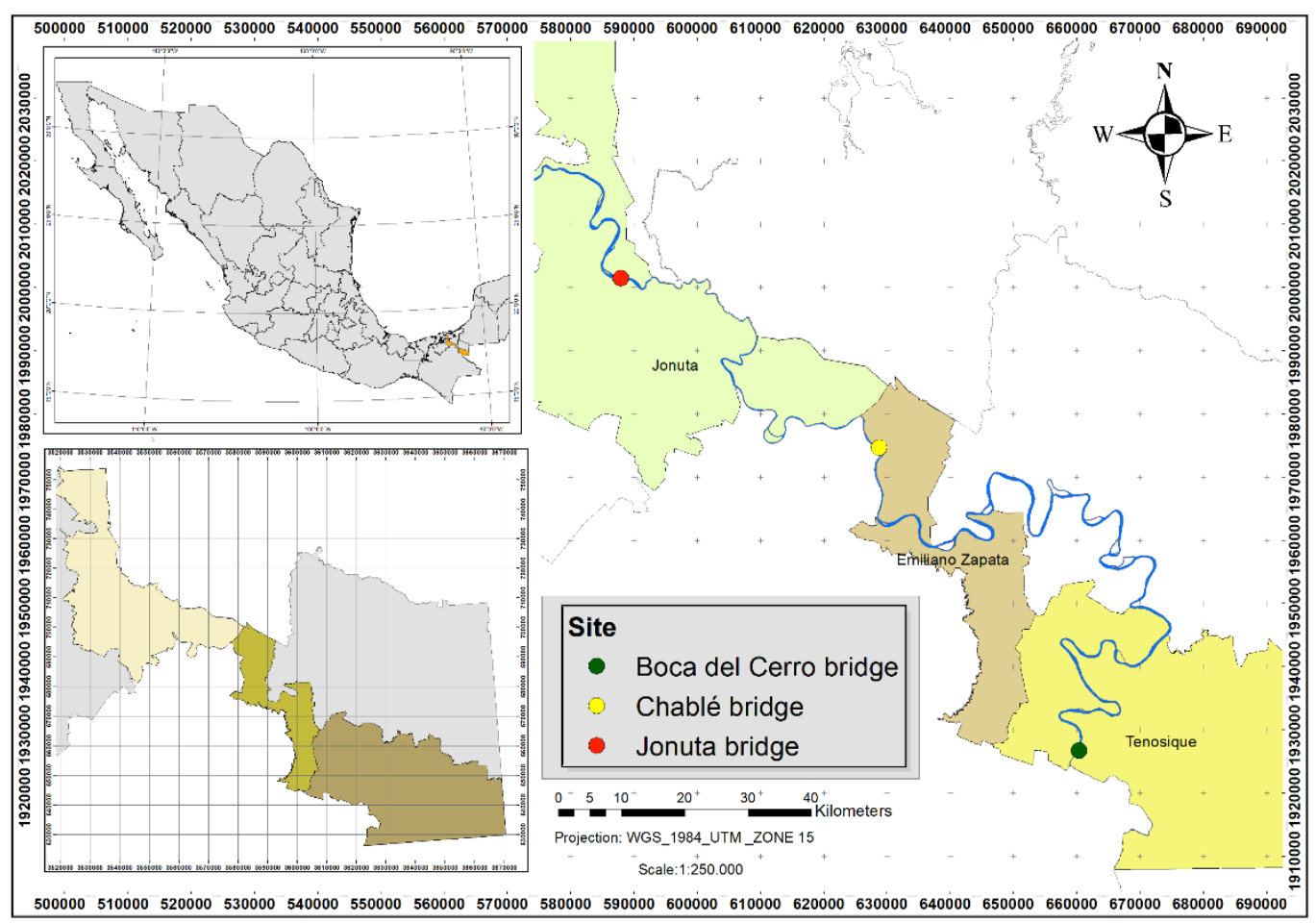

Fig. 1: Location of sampling sites in the lower basin of the Usumacinta River, Tabasco. 
Table 2: Concentration of total suspended solids (TSS) recorded at sampling sites and mentioned in Normativity of Mexico and the USA (mg.L L $^{-1}$.

\begin{tabular}{|c|c|c|c|c|c|}
\hline \multirow[t]{2}{*}{ Statistical } & \multicolumn{3}{|l|}{ TSS Concentration } & \multicolumn{2}{|l|}{ Normativity } \\
\hline & R1 Boca del Cerro & R2 Chablé & R3 Jonuta & CE-CCA-001/89 & US-EPA-2001/2003 \\
\hline Media & 95.70 & 91.10 & 69.94 & & \\
\hline Standard Dev. & 35.22 & 74.18 & 43.97 & $50^{\mathrm{a}}$ & $50^{\mathrm{a}}$ \\
\hline Maximum & 130.92 & 165.28 & 113.91 & $500^{\mathrm{b}}$ & $150^{\mathrm{c}}$ \\
\hline Minimum & 60.48 & 16.92 & 25.96 & & \\
\hline
\end{tabular}

(a): For agricultural irrigation; (b): For drinking water supply source; (c): For protection of freshwater aquatic life.

tionally, with the Water Quality Criteria of the United States Environmental Protection Agency (US-EPA 2001/2003).

\section{Water Erosion}

Water erosion was determined based on the Universal Soil Loss Equation (USLE) (Wischmeier \& Smith 1978), and the ArcGIS information system (version 10.3) with which the georeferenced information is represented. The equation consists of six factors that influence the erosion process:

$$
A=R^{*} K^{*} L S^{*} C P
$$

In which $A$ is the estimation of average annual soil loss (tons.ha ${ }^{-1} \mathrm{yr}^{-1}$ ); $R$ is the rainfall erosivity factor, accounts for the energy and intensity of rainstorms (MJ.mm.ha ${ }^{-1} \mathrm{~h}^{-1}$ ); $K$ is the soil erodibility factor and measures the susceptibility of a soil to erode under a standard condition (tons.h. $\mathrm{MJ}^{-1} \mathrm{~mm}^{-1}$ ); $L S$ is the slope length and steepness factor, accounts for the effect of length and steepness of slope on erosion; $C$ is the cover and management and crop factor and estimates the soil loss ratio for 4 or 5 crop stage periods throughout the year, accounting for the combined effect of all the interrelated cover and management variables; $P$ is the support practice factor, accounts for the effect of conservation support practices, such as contouring, contour strip cropping, and terraces on soil erosion.

For the determination of each of the factor, the annual precipitation obtained from the database of the Ensenada Scientific Research Center and Higher Education databases (CLICOM 2017) and the digital elevation model of the basin in scale 1: 50,000 (INEGI 2015) were used, in addition to the granulometry and soil texture data generated in this study. Also, the types of land use and vegetation of the study area were considered (INEGI 2016).

\section{RESULTS}

\section{Total Suspended Solids}

The results of maximum TSS concentrations obtained at site R1 (130.92 mg.L $\left.{ }^{-1}\right)$, R2 (165.28 mg.L $\left.{ }^{-1}\right)$, and R3 (113.91 mg
$\mathrm{L}^{-1}$ ) comply with the ecological criteria for water quality (CE-CCA -001/89) established for water supply sources, however, exceeding the criteria for agricultural irrigation use. According to the Environmental Protection Agency (US-EPA 2001/2003), the quality criteria for drinking water supply sources are not met, noting that site R2 exceeds the limits that guarantee the protection of aquatic life in freshwater (Table 2). In general, the water quality of the river is worse in the upper part of the lower basin, although the maximum TTS concentration was observed in the middle part of it. The water quality is good for irrigation and river ecology but it is bad for drinking purposes and needed treatment considering this parameter among many others. It should be noted that the Usumacinta River is the principal source of drinking water supply for the municipalities of Tenosique (Boca del Cerro) and Jonuta.

The concentration of TSS registered in Boca del Cerro (R1) was $163 \mathrm{mg} . \mathrm{L}^{-1}$. In the rainy season, June is when the highest TSS concentration was recorded, while in the dry season, for April and May, concentrations of TSS were not detected (Fig. 2).

Regarding the concentration of total suspended solids registered in Chablé, during the rainy season (in June 2018), it was $300 \mathrm{mg} \cdot \mathrm{L}^{-1}$. On the other hand, in the dry season (in May 2018 and 2019), the detected concentration was $13 \mathrm{mg}$ $\mathrm{L}^{-1}$ (Fig. 3). Furthermore, the concentration of TSS recorded in Jonuta was $133 \mathrm{mg} . \mathrm{L}^{-1}$ at the end of June. In May (2018 and 2019), the concentration of TSS detected was $14 \mathrm{mg} . \mathrm{L}^{-1}$, while at the end of the dry season, in the first week of June, it was $18 \mathrm{mg} . \mathrm{L}^{-1}$ (Fig. 4).

\section{Rainfall Erosivity factor (R)}

Results obtained in this study show that the municipality of Jonuta has the lowest erosivity value $(24,225.14$ MJ.mm. $\mathrm{ha}^{-1} \mathrm{~h}^{-1}$ ), while its average annual rainfall is $1,805 \mathrm{~mm}$. On the other hand, Tenosique (where the sampling site Boca del Cerro is located) presents a maximum value of $36,258.55$ MJ.mm.ha ${ }^{-1} \mathrm{~h}^{-1}$ while its average annual rainfall is 2,250 


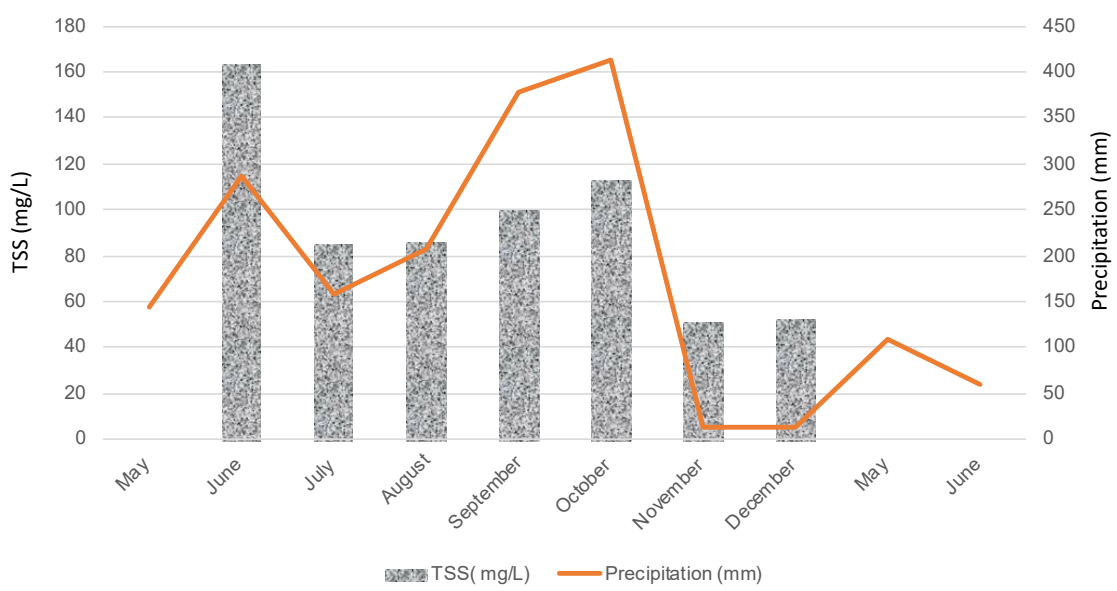

Fig. 2: TSS concentration registered in Boca del Cerro (R1) in the rainy season (June-November, 2018) and dry season (December-May, 2019).

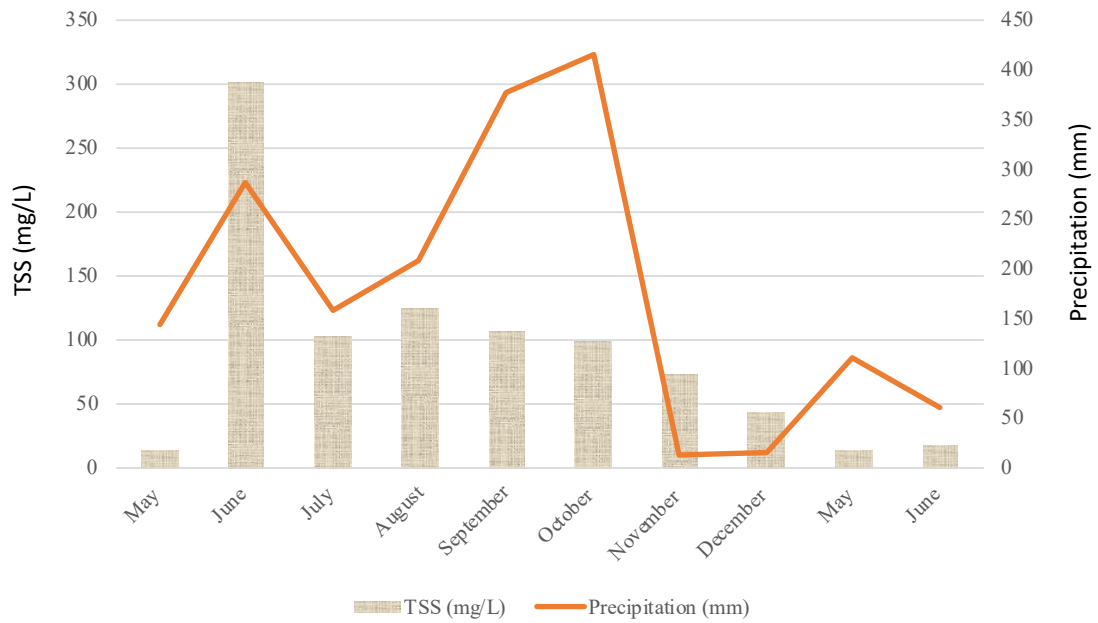

Fig. 3: TSS concentration recorded in Chable (R2) in the rainy season (June-November, 2018) and dry season (December-May, 2019).

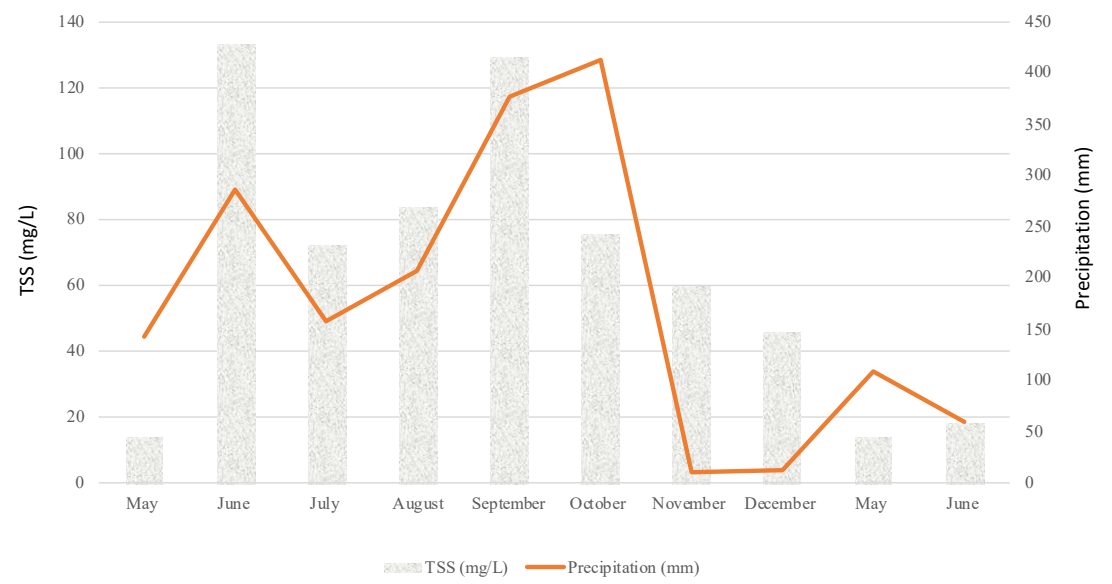

Fig. 4: TSS concentration recorded in Jonuta (R3) in the rainy season (June-November, 2018) and dry season (December-May, 2019). 
mm (Fig. 5). It was observed that the area with the highest potential energy (in raindrops) corresponds to the municipality of Tenosique.

\section{Soil Erodibility Factor $(\mathbf{K})$}

A range of values between $0.23-0.89$ tons.h. $\mathrm{MJ}^{-1} \mathrm{~mm}^{-1}$ was obtained within the study area. The municipality of Emiliano Zapata was the area with the greatest susceptibility to erosion (Fig. 6).

\section{Slope-Length factor (LS)}

Results obtained in this study show that the municipality of Tenosique, where the town of Boca del Cerro is located, presents a slope value of $16 \%$ being a territory prone to erosion. On the contrary, Jonuta presents a value of $0.03 \%$, which makes it stable against erosion (Fig. 7). It is observed that the highest factor ( $\mathrm{LS}=27,423$ ) is associated with the steepest slopes located in the municipality of Tenosique, and the lowest value ( $\mathrm{LS}=0.03$ ) was registered in the municipality of Jonuta (Fig. 8).

\section{Cover Management and Crop Factor (C)}

In the municipality of Jonuta, there are areas with little natural vegetation and water bodies. On the contrary, in the municipalities of Emiliano Zapata (where the sampling site

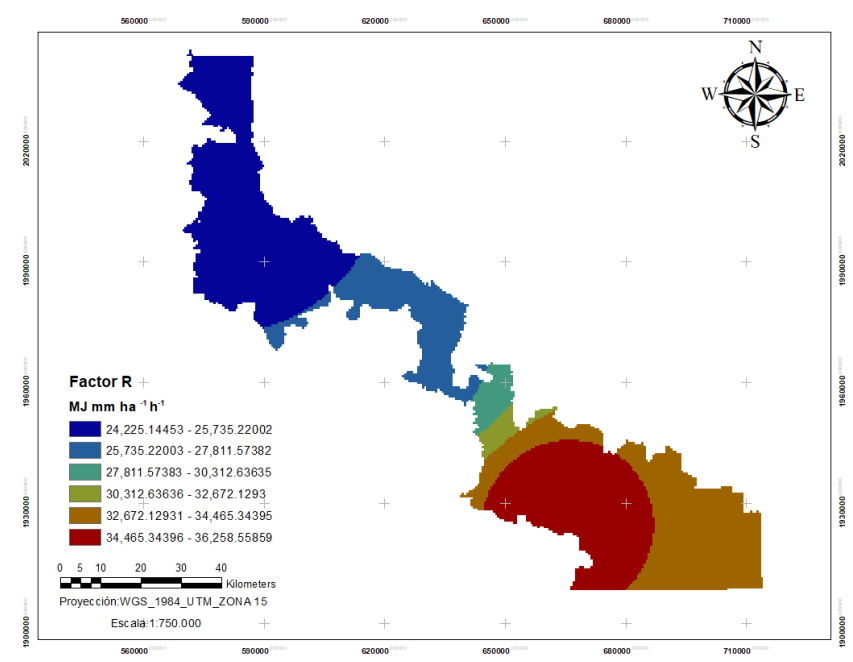

Fig. 5: Distribution of erosivity (Factor R) in the lower basin of the Usumacinta River, Tabasco.

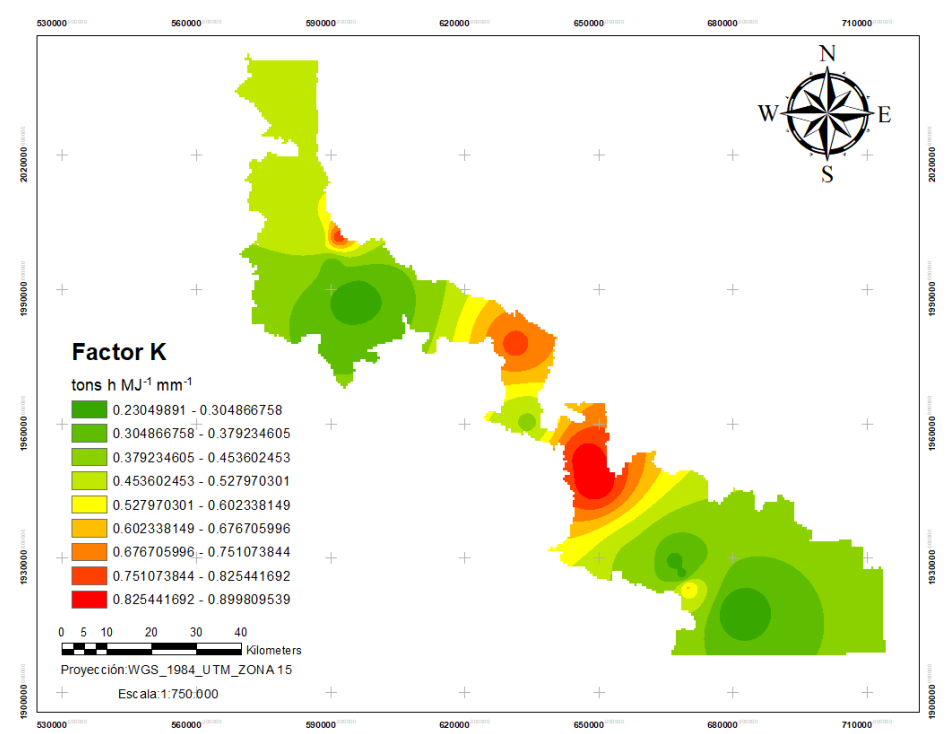

Fig. 6: Distribution of soil erodibility (K Factor) in the lower basin of the Usumacinta River, Tabasco. 


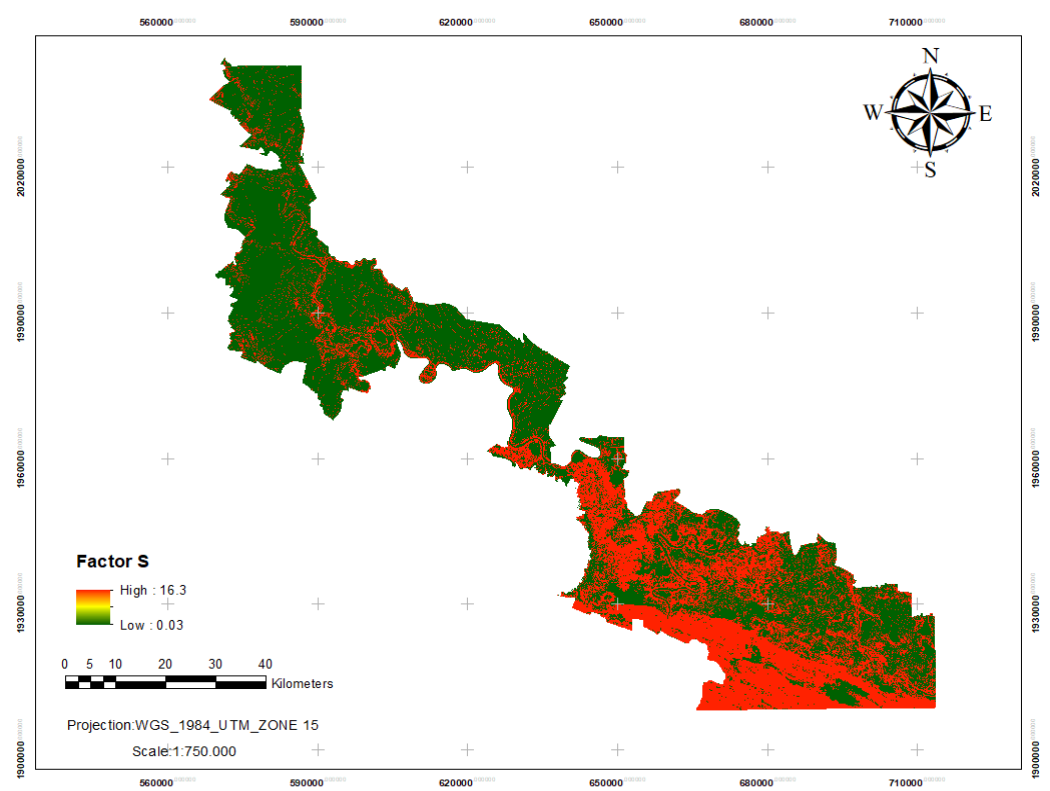

Fig. 7: Degree of steepness (Factor S) in the lower basin of the Usumacinta River, Tabasco.

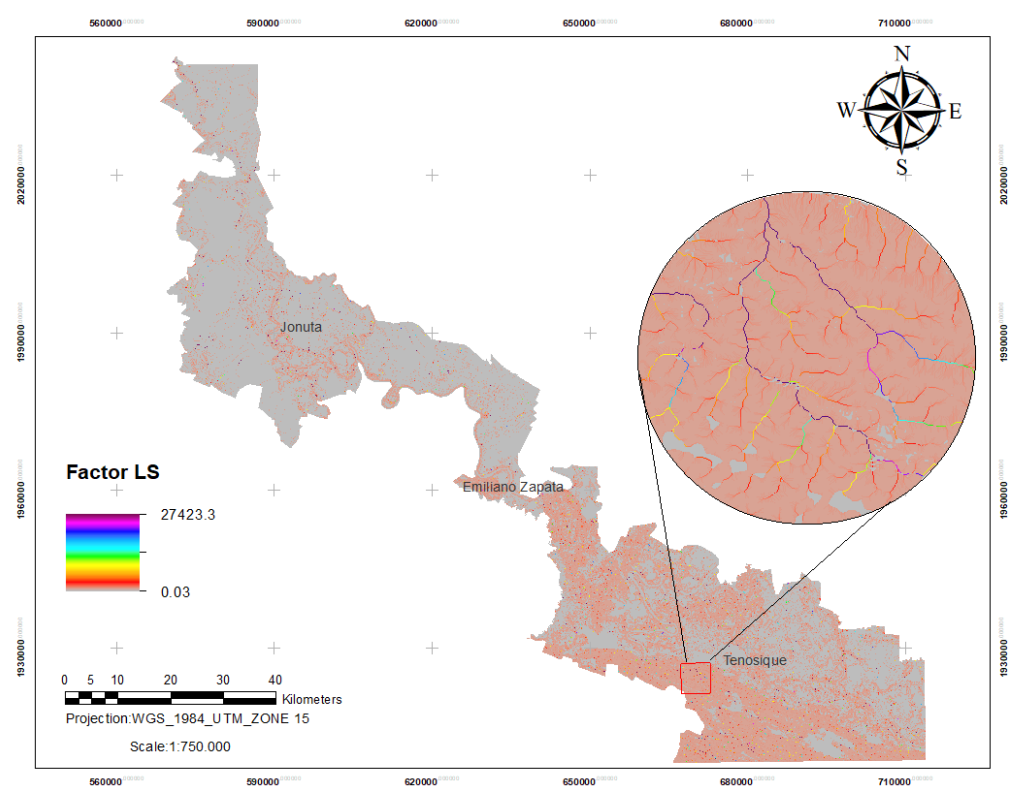

Fig. 8: Slope-length factor (LS) in the lower basin of the Usumacinta River, Tabasco.

of Chablé is located) and Tenosique, there are jungles along $\mathrm{ha}^{-1} \mathrm{yr}^{-1}$, respectively (Fig. 10). with agricultural lands and pastures (Fig. 9).

\section{Water Erosion}

The results obtained from average annual erosion in Tenosique (Boca del Cerro), Emiliano Zapata (Chablé), and Jonuta are 990 tons.ha $^{-1}$ year $^{-1}$, 174 tons.ha $^{-1}$ year $^{-1}$, and 65.tons.

\section{DISCUSSION}

\section{Total Suspended Solids}

In the lower basin of the Usumacinta River, concentrations of total suspended solids between 13 and $18 \mathrm{mg} . \mathrm{L}^{-1}$ were 


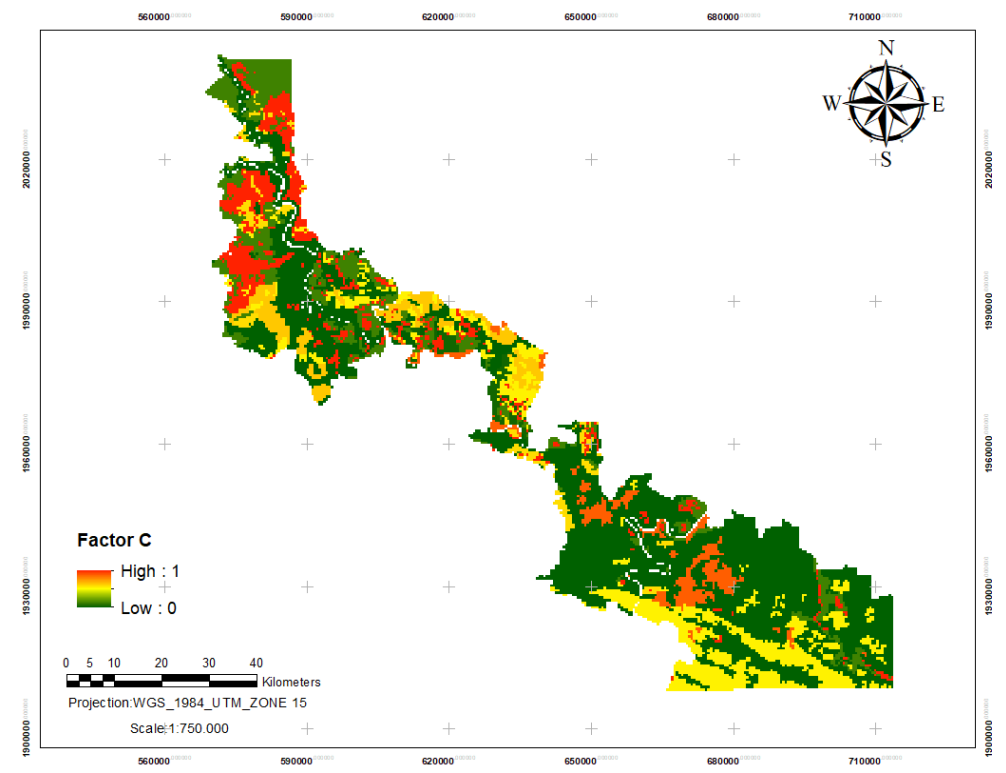

Fig. 9: Cover management and crop factor (C) in the lower basin of the Usumacinta River, Tabasco.

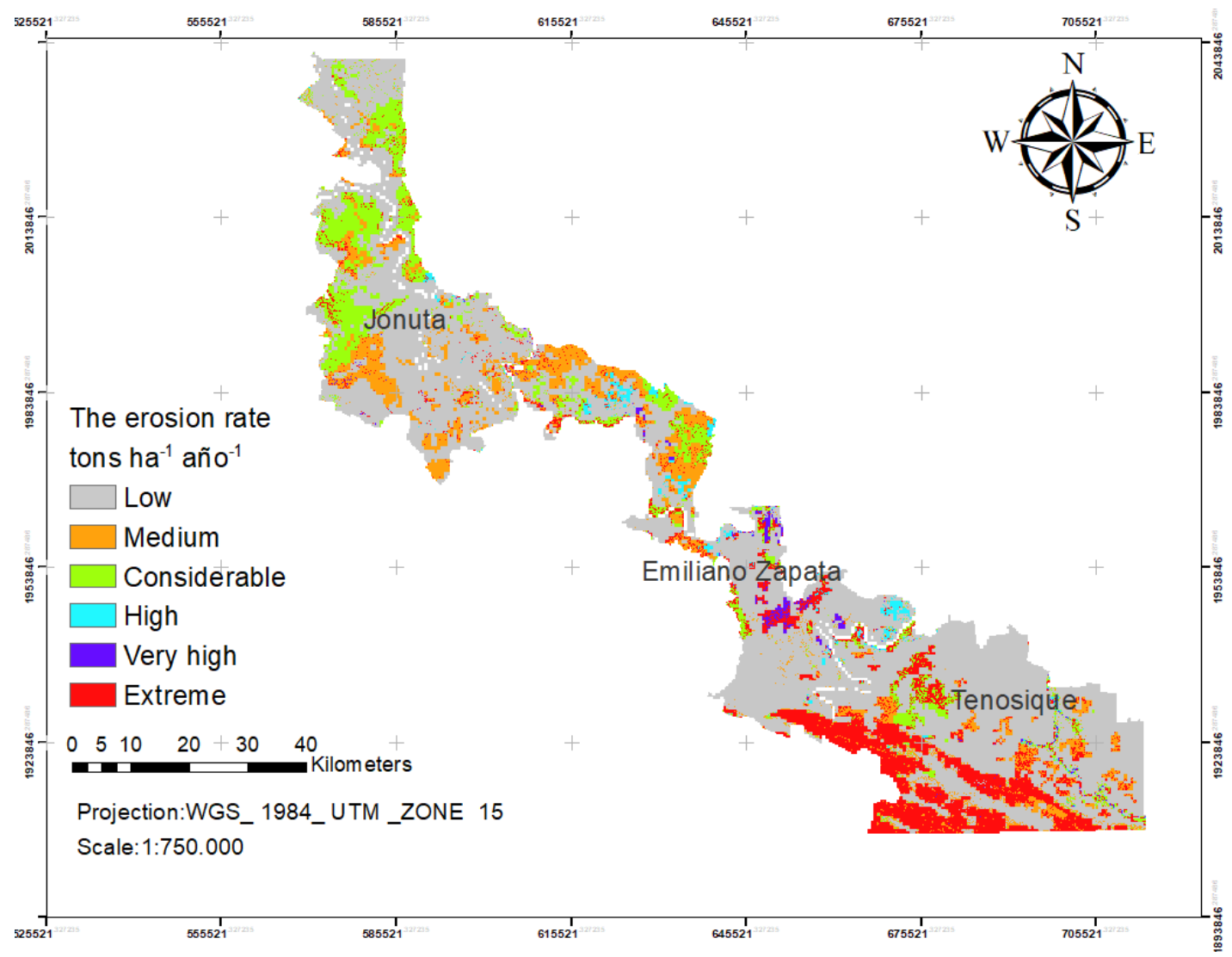

Fig. 10: Erosion rate in the lower basin of the Usumacinta River, Tabasco, Mexico. 
registered in the dry season; and from 72 to $300 \mathrm{mg} . \mathrm{L}^{-1}$ in the rainy season. According to Laino-Guanes et al. (2016), rivers in the state of Tabasco reported TSS concentrations between $1.8 \mathrm{mg} . \mathrm{L}^{-1}$ and $4.3 \mathrm{mg} . \mathrm{L}^{-1}$ in the dry season, and $31.1 \mathrm{mg} . \mathrm{L}^{-1}$ and up to $548.8 \mathrm{mg} . \mathrm{L}^{-1}$ in the rainy season. This increase in TSS concentrations may be due to the dragging of material accumulated or deposited on the banks of the effluents in the dry season, or by landslides and loss of soil due to erosion in the rainy season (Almazán-Juárez et al. 2016). The TSS concentrations are associated with turbidity. Kulkarni (2011), indicated that TSS values greater than $1000 \mathrm{mg} . \mathrm{L}^{-1}$ affect the entry of light, limiting the development of aquatic life, as well as making possible the transport of toxic substances when there are small particles (less than $63 \mu \mathrm{m}$ ).

\section{Rainfall Erosivity factor (R)}

Erosivity factor $(\mathrm{R})$ in territories is correlated with the rainfall present, Cerdà (2001) mentioned that the greater the intensity of the precipitation, the greater the raindrops, and thus the loss of soil increases. Tenosique presents a maximum value of 36,258.55 MJ.mm.ha ${ }^{-1} \mathrm{~h}^{-1}$ associated with a mean annual rainfall of 2,250 mm (Fig. 5), considered the municipality with the highest potential energy (in raindrops). In this regard, López and Romero (1993), point out that rainfall of 100 $\mathrm{mm}$ to $300 \mathrm{~mm}$ registered in a few hours, releases enormous amounts of energy reflected in high soil losses, sinkholes, embankments, thick layers of sediments, and floods, as observed in the study area and sampling sites. Losses of soil due to water erosion can affect agricultural activity in this regard, López et al. (2003), mention that as a consequence of the impoverishment of the soil and loss of its productivity, the effects on crop yields arise, and fertilization requirements also increase, in addition to the difficulty in tillage.

\section{Soil Erodibility Factor $(\mathbf{K})$}

Soil erodibility is related to the stability of the aggregates and the cohesion forces that hold them together with the texture. The types of soil that predominate in this area are vertisols and gleysols, which are soils with a slow permeability characteristic (Palma-López 2007). A range of values between 0.23-0.89 tons.h. $\mathrm{MJ}^{-1} \mathrm{~mm}^{-1}$ was obtained within the study area. The municipality of Emiliano Zapata was the area with the greatest susceptibility to erosion. This municipality has an area of 31,492 ha for livestock (INEGI 2016). This implies the use of heavy machinery and trampling by the cattle that generates superficial compaction, altering the structure of the soil, thus, decreasing permeability. Furthermore, the nature of the soil increases erosion, lowers its permeability and the cohesion of its elements (structure) (Alfonso-Linares \& Monedero-García 2004). According to Duarte (2006), phenomena such as erosion, compaction, reduction in depth, acidification and decrease in biological activity, loss of nutrients, pesticides, and sediments from agricultural plots to surface and groundwater increases (Fig. 6).

\section{Slope-Length Factor (LS)}

The slope-length factor (LS) represents the effect of slope length on erosion. Results obtained in this study show that the municipality of Tenosique, where the town of Boca del Cerro is located, presents a slope value of $16 \%$ being a territory prone to erosion. On the contrary, Jonuta presents a value of $0.03 \%$, which makes it stable against erosion. It is also observed that the highest LS factor is associated with steeper slopes and low values occur in plains areas (Figs. 7, 8). According to Alvarado-Cardona et al. (2007), the parts of a basin that present the greatest risk of erosion are those slopes greater than $25 \%$.

\section{Cover Management and Crop Factor (C)}

According to the coverage of the basin, the cover management and crop factor varies from 0.1 to 0.85 , considering the value of 1 for water bodies (Fig. 9). In the municipality of Jonuta, there are areas with little vegetation and water. This makes it an area susceptible to erosion. This municipality has an area of 3,151 ha for agriculture and 129, 202 ha for livestock (INEGI 2016). On the contrary, in the municipalities of Emiliano Zapata (Chablé sampling site) and Tenosique (Boca del Cerro sampling site), there are jungle areas. In this regard, García-Fayos (2004) mentioned that vegetation influences erosion by increasing the stability of the soil aggregates, protecting it from the impact of drops of water, increasing the infiltration capacity, and stopping runoff, as could be seen in this study. Despite this and generated by the change in land use to activities such as agriculture and livestock, there is a loss of 427 ha. $^{-1} r^{-1}$ of vegetation (CONANP 2010).

\section{Water Erosion}

According to Montes-León et al. (2011), water erosion was classified into six ranges, which are: low $\left(<50\right.$ tons.ha $\left.{ }^{-1} \cdot \mathrm{yr}^{-1}\right)$, medium (50-100 tons.ha $\left.{ }^{-1} \mathrm{yr}^{-1}\right)$, considerable (100-150 tons. ha $\left.^{-1} \mathrm{yr}^{-1}\right)$, high (150-200 tons.ha $\left.{ }^{-1} \mathrm{yr}^{-1}\right)$, very high (200-250 tons.ha ${ }^{-1}$ year $^{-1}$ ), and extreme (> 250 tons.ha $\left.{ }^{-1} \mathrm{yr}^{-1}\right)$. Thus, the results of erosion in the lower basin of the Usumacinta River ranges from low to extreme, Jonuta is classified as low $\left(<50\right.$ tons. $\left.\mathrm{ha}^{-1} \mathrm{yr}^{-1}\right)$, Emiliano Zapata as medium (50-100 tons. $\left.\mathrm{ha}^{-1} \mathrm{yr}^{-1}\right)$, and Tenosique as extreme (> 250 tons.ha $\left.^{-1} \mathrm{year}^{-1}\right)$. There is a combination of factors that accelerates the erosion phenomenon in the upper part of the lower basin of the Usumacinta River, causing areas with extreme erosion to appear (Fig. 10), just as it was observed in the municipality 
of Tenosique - unlike those reported by Sánchez-Hernández et al. (2013), where $83 \%$ of the Grijalva-Usumacinta basin presented a medium to a high level of erosion, and only $17 \%$ presented a low level of risk.

\section{CONCLUSION}

According to the current situation of water erosion in the lower basin of the Usumacinta River in the state of Tabasco, there are areas with extreme erosion, a product of a steep slope, high rainfall, and clay soils that are dedicated to agriculture and livestock. A certain pattern has been established in the distribution of territorial water erosion (TWE), total suspended solids (TSS), and the water quality (WQ) of the Usumacinta River in its lower basin. WQ is good for aquatic life and agricultural irrigation in its lower basin. The mean annual TSS value is greater in the upper part of the lower basin (municipality of Tenosique) than in other parts of the basin and is equal to $95.7 \mathrm{mg} . \mathrm{L}^{-1}$. This is due to the intense water erosion of the soil $\left(\mathrm{TWE}=990 \mathrm{t} \cdot \mathrm{ha}^{-1} \cdot \mathrm{year}^{-1}\right)$, a product of a steep slope (greater than 16\%), high rainfall (greater than $1805 \mathrm{~mm} \cdot \mathrm{yr}^{-1}$ ), and clay soils used for agriculture and pastures. Therefore, it is necessary to provide measures to reduce soil erosion by considering soil conservation technologies and surface water runoff control. In the downstream parts of the basin with significantly lower surface slopes, the TSS and TWE values are $91.10 \mathrm{mg} . \mathrm{L}^{-1}$ and 174 t.ha $^{-1} \mathrm{yr}^{-1}$ in the municipality of Emiliano Zapata, and $69.94 \mathrm{mg} . \mathrm{L}^{-1}$ and $65 \mathrm{t}^{-h a^{-1}} \mathrm{yr}$ in the municipality of Jonuta. Such distribution of TSS values indicates the influence of local factors and less corresponds to the upstream parts of the river. The influence of municipal wastewaters on the TSS value can be neglected because its volume is insignificant compared to the river flow in the rainy season. However, this influence cannot be ruled out because the treatment plants of each municipality in the study area do not operate, or do not operate properly, which causes environmental and health problems in the dry season.

\section{ACKNOWLEDGEMENT}

To the National Water Commission (CONAGUA) and to the National Council of Science and Technology (CONACYT) 2014-248265 Project "Evaluation of the effect of diffuse sources of pollution on the quality of the water of the Usumacinta River, in the state of Tabasco. To the Postgraduate College, Veracruz Campus; and the Boca del Río Technological Institute.

\section{REFERENCES}

Alfonso-Linares, C. A. and Monedero-García, M. 2004. Uso, manejo y conservación de suelos. Asociación Cubana de Técnicos Agrícolas y Forestales. La Habana, Cuba., pp. 68.
Almazán-Juárez, M. T., Almazán-Juárez, Á., Carreto-Pérez, B. E., Hernández, E., Castro, A. D. N. and Almazán-Núñez, R. C. 2016. Calidad y clasificación de usos del agua en la cuenca baja del río Papagayo, Guerrero México. Ecosistemas y Recursos Agropecuarios, 3(9): 293-305.

Alvarado-Cardona, M., Colmenero, R.J.A. and Valderrábano, A.M.L. 2007. La erosión hídrica del suelo, en un contexto ambiental, en el estado de Tlaxcala. Ciencia ergo sum 14(3): 317-326.

Cerdà, A. 2001. La erosión del suelo y sus tasas en España. Revista ecosistemas, Madrid, España, 10(3). Available in: https:// www.revistaecosistemas.net/index.php/ecosistemas/article/ download/268/264

CE-CCA-001/89. 1989. Criterios Ecológicos de Calidad del Agua. Diario Oficial de la Federación, México. Available in: http://www.dof.gob. $\mathrm{mx} /$ nota_detalle.php?codigo $=4837548 \&$ fecha $=13 / 12 / 1989$

CONAGUA. 2018. Estadísticas del agua en México. CONAGUA, México. 294 pp. Available in: http://sina.conagua.gob.mx/publicaciones/ EAM_2018.pdf

CONANP. 2010. Comisión Nacional de Áreas Naturales Protegidas 2010. Identificación de cambios en el uso del suelo y vegetación, y cálculo de la tasa de transformación del hábitat en el periodo 2000-20210. Área de protección de flora y fauna "Cañon del Usumacinta". 55 pp.

Duarte, A.F.C. 2006. Contaminación difusa originada por la actividad agrícola de riego, a la escala de la cuenca hidrográfica. Tesis doctoral, Universidad de Córdoba. Escuela técnica superior de ingenieros agrónomos y montes.

García-Fayos, P. 2004. Interacciones entre la vegetación y la erosión hídrica. Pp:309-334. En: Valladares, F.2004. Ecología del bosque mediterráneo en un mundo cambiante. $2^{\text {a }}$ edición. Ministerio de Medio Ambiente, EGRAF, S.A., Madrid. ISBN: 84-8014-552-8.

INEGI. 2016. Anuario estadístico y geográfico de Tabasco, México. 461p Available in: http://internet.contenidos.inegi.org.mx/contenidos/ Productos/prod_serv/contenidos/espanol/bvinegi/productos/nueva_ estruc/anuarios_2016/702825084363.pdf

Kulkarni, A. 2011. Water quality retrieval from landsat TM imagery. Procedia Comp. Science, 6: 475-480. https://doi.org/10.1016/j. procs.2011.08.088

Laino-Guanes, R., González-Espinosa, M., Ramírez-Marcial, N., BelloMendoza, R., Jiménez, F., Casanoves, F. and Musálem-Castillejos, K. 2016. Human pressure on water quality and water yield in the upper Grijalva river basin in the Mexico-Guatemala border. Ecohydrology \& Hydrobiology, 16(3): 149-159.

López, H.E.F., Menes, M.M., Mota, J.L.O., Saens, E.M. and González, R.C. 2003. Integración de la EUPS a un SIG para estimar la erosión hídrica del suelo en una cuenca hidrográfica de Tepatitlán, Jalisco, México. Terra Latinoamericana, 21(2): 233-244.

López, B.F. and Romero D.M.A. 1993. Génesis y consecuencias erosivas de las lluvias de alta intensidad en la región mediterránea. Cuadernos I: Geográfica Vol. 18,19: Ediciones Logroño, España., pp. 7-28.

March, M.I. and Castro, N. 2010. La Cuenca del Río Usumacinta: Perfil y perspectivas para su conservación y desarrollo sustentable. Las cuencas hidrográficas de México. Diagnóstico y priorización. México DF: SEMARNAT-INE-Gonzálo Río Arronte, IAP., pp. 193-197.

Montes-León, M.A.L., Uribe-Alcántara, E.M. and García-Celis, E. 2011. Mapa nacional de erosión potencial. Tecnología y ciencias del agua, 2(1): 05-17.

NMX-AA-034-SCFI-2015. Norma Mexicana. Análisis de agua- Medición de sólidos y sales disueltas en aguas naturales, residuales y residuales tratadas- Método de prueba.

Palma-López, D.J., Cisneros, D.J., Moreno, C.E. and Rincón-Ramírez, J.A. 2007. Suelos de Tabasco: su uso y manejo sustentable. Colegio de Postgraduados-ISPROTAB-FUPROTAB. Villahermosa, Tabasco, México., pp. 195. 
Paz González, A. and Vidal Vázquez, E. 2004. Erosión y Escorrentía. Universidad de La Coruña. Facultad de Ciencias. España., pp. 11.

Sánchez-Hernández, R., Mendoza-Palacios, J., De la Cruz Reyes, J., Mendoza-Martínez, J. and Ramos-Reyes, R. 2013. Mapa de erosión potencial en la cuenca hidrológica Grijalva-Usumacinta México mediante el uso de sig. Universidad y Ciencia, 29 (2): 153-161.

Soares, D. and García, A.G. 2017. La cuenca del río Usumacinta desde la perspectiva del cambio climático. Instituto Mexicano de Tecnología del Agua, México., pp. 425.

US EPA 2001. Parameters of water quality: Interpretation and standards.
Environmental Protection Agency. Johnstown Castle, Ireland., pp. 132.

US EPA 2003. Developing water quality criteria for suspended and bedded sediments (SABS). US EPA Office of Water.

Vargas, V.B. and Linero, C. J. 2017. Caracterización de sólidos suspendidos y sedimentos superficiales en humedales del departamento del Magdalena (Zapayán, Pijiño y Chilloa). 212-216 pp. In: Memorias III Seminario Internacional de Ciencias Ambientales, SUE- Caribe, 2017.

Wischmeier, W.H. and Smith, D.D. 1978. Predicting rainfall erosion losses: A guide to conservation planning. Washington, D.C., U.S. Dep. Agric., Agric. Handb. No. 537, 1978. 